\title{
Analysis of Financial Performance of Selected Commercial Banks in India
}

\author{
Palamalai Srinivasan*, John Britto \\ Xavier Institute of Management \& Entrepreneurship, Bangalore, India \\ Email: *srinivasaneco@gmail.com, johnbritto23@gmail.com
}

How to cite this paper: Srinivasan, P. and Britto, J. (2017) Analysis of Financial Performance of Selected Commercial Banks in India. Theoretical Economics Letters, 7, 2134-2151. https://doi.org/10.4236/tel.2017.77145

Received: November 3, 2017

Accepted: December 10, 2017

Published: December 13, 2017

Copyright $\odot 2017$ by authors and Scientific Research Publishing Inc. This work is licensed under the Creative Commons Attribution International License (CC BY 4.0).

http://creativecommons.org/licenses/by/4.0/

\section{c) (i) Open Access}

\begin{abstract}
The present study attempts to evaluate the financial performance of selected Indian commercial banks for the period from 2012/13 to 2016/17. The study comprises 16 commercial banks, 11 representing public sector and 5 from private sector, and the financial performance of these banks are analysed using the financial ratios. The study shows that the financial performance of private sector banks is relatively better than the public sector banks throughout the study period. Besides, the study examines the impact of liquidity, solvency and efficiency on the profitability of the selected Indian commercial banks by employing the panel data estimations, viz. the Fixed Effect and Random Effect models. The empirical results from the panel data estimations revealed that the liquidity ratio and solvency ratio, and the turnover ratio and solvency ratio are found to have positive and significant impact on the profitability of selected public sector and private sector banks, respectively, bearing testimony to the fact that profitability is a function of those ratios.
\end{abstract}

\section{Keywords}

Financial Performance, Profitability, Solvency, Liquidity, Commercial Banks

\section{Introduction}

Solvency and liquidity are very significant for banks since its assets and loans have diverse maturities. Banks have the principal role of converting liquid deposit (liabilities) to illiquid assets such as loans, which makes them intrinsically vulnerable to liquidity risk. Lack of liquidity is an indicator of the liquidity crisis in a banking system and therefore liquidity management is an imperative objective for the commercial banks since illiquidity may results in insolvency and deprived financial performance. Liquidity elucidates the bank's potential to manage its short 
duration liability. In other words, the liquidity management shows how efficiently a bank manages its short duration requirement and invests the funds to raise the profitability of the organization. Therefore, the optimum level of liquidity guarantees a bank to meet their short term debts and the proper management of flow can be promised by a profitable business. Besides, the illiquidity will lead to insolvency and bankruptcy as the liabilities surpass its assets. It is impossible for banks to endure without making profits and there exists positive association between liquidity and profitability, which implies that lower liquidity position may result in lower profitability due to greater requirement for loans, and low profitability would not generate sufficient cash flows, thus creating a viscous cycle [1]. Besides, the liquidity is negatively associated with profitability of the banks because of holding liquid assets tend to condense income due to the lower rates of return connected with liquid assets [2].

Solvency represents the association between borrowed funds and owner's funds in the capital structure of a bank. It comprises debt and common equity for financing the bank's total assets, operations and financial growth [3]. The Capital adequacy norms curb the banks in their liberty of capital structure. The enforcement of capital adequacy ratio may have negative impact on the profitability of the banks. It has been stated that agency costs between managers and shareholders tend to increase when capital ratios are higher due to the discipline provided by debt repayment on managers' behaviour [4]. However, the increased surplus engendered as result of healthy bank-borrower relationship and enhanced monitoring laid down by the capital adequacy norms would have positive impact on the banks' profitability [5]. Moreover, the capital adequacy norms target at stability of the banks and thereby reduce the riskiness of the assets in the portfolio of the banks.

Management of liquidity and solvency ratios are vital for the commercial banks as it associated with their performances and reputations, especially with profitability ratios. If the banks have poor liquidity conditions, the regulators will penalize them and therefore it becomes imperative for the banks to keep a sound liquidity arrangement. Healthy financial performance has become a great challenge in the modern times as banks are characterised by the technological advancements, high competition for consumer deposits and altering monetary policy that augments the liquidity, solvency and the profitability of the banks. The present study attempts to evaluate the financial performance of selected Indian commercial banks using the financial ratios, and also examines the impact of liquidity, solvency and efficiency on the profitability of the selected Indian commercial banks by employing the panel data estimations, viz. the Fixed Effect and Random Effect models. The study will throw light on financial performance of the commercial banks which will help policy makers, regulator (Reserve Bank of India), Governments and other stakeholders to devise targeted policies and regulations that will dynamically stimulate the growth and sustainability of the commercial banks in the country. The study is of great importance for academics to 
compare the performances of various commercial banks and efforts should be made to solve the discrepancies in performances of those banks. Besides, the study is immense help for the management and staff of commercial banks who will gain insight into how their institutions can effectively manage their financial ratios by appropriate practices to increase their profits.

\section{Review of Literature}

[6] examined the performance of Bahrain's commercial banks with respect to credit (loan), liquidity and profitability positions and found that the commercial banks are relatively less profitable and have less liquid and exposed to risk. [7] found that the operational efficiency, asset management and bank size are positively influenced the financial performance of the Omani commercial banks. [8] used financial ratios for the South Africa and found that banking performance was deteriorated significantly after the global financial crisis of 2007. [9] studied for seven Jordanian commercial banks and found that there is a strong negative correlation between ROA and bank size and with operational efficiency and positive correlation between ROA and asset management ratio. [10] examined the financial performance of five Palestine commercial banks and found that the credit risk, asset management, bank size and operational efficiency have a positive association with bank performance. [11] evaluated the financial performance of foreign and domestic banks in Turkey using financial ratios and found that the management effectiveness, total assets, return on equity and asset quality of domestic banks are better than that of foreign banks. However, foreign banks have higher capital adequacy ratio than domestic banks.

[12] found no significant relationship between the bank's performance and their key explanatory variables in Bangladesh. While [13] analysed for commercial banks in Bangladesh and revealed that the credit risk and bank size are significant and negatively related to ROA. [14] applied CAMEL model and found that profitability of Kenyan banks is significantly related to capital adequacy, asset quality and management efficiency. However, the relationship with ownership is found to be insignificant.

[15] focused on determinants of bank profitability in India and found that the profit margins deteriorated due to increased competition and changing face of the Indian banking. [16] reported that the Indian public sector banks were most efficient than the private and foreign banks in terms of cost and profit efficiencies. [17] examined the financial performance of SBI (State Bank of India) using the investment valuation ratio, profitability ratio, management efficiency ratio, balance sheet ratio, and cash flow indicators. They suggested that SBI's excellent performance can be attributed to the adoption of modern technology, banking reforms, and good recovery mechanisms. [18] has done comparative analysis of the financial performance of Indian commercial banks and disclosed that there is no statistically significant difference in the financial performance of the public and private sector banks in India. [19] found no significant difference in the 
profitability of Indian commercial banks in terms of net interest margin and return on assets, but have significant differences in terms of return on equity. Recently, [20] showed significant differences among the financial performance of commercial banks operating in India. Besides, [21] evaluated the financial, operational, and managerial efficiency of the selected largest scheduled commercial banks in India with different ownership structure, such as public (State Bank of India), private (ICICI Bank), and foreign bank (Standard Chartered Bank). The findings revealed that there was no difference statistically among these banks in terms of ratios and performance of sub-parameters namely, debt/equity ratio, gross non-performing assets/total assets, income interest/total assets, and liquid assets to total deposits during the research. However, the study showed that the foreign bank is significantly more efficient than the private and public banks in terms of profitable banking business and converting deposits into higher earning advances.

It is clear from the existing literature that the studies pertaining to the financial performance of commercial banks across the globe, especially in Indian context, are performed based on the ratio analysis and CAMEL ranking method. Besides there have been studies which proved that there has been significant difference in the performance of public and private sector banks in India [18] [20] [22] [23]. However, the analysis has been done on the basis of aggregate financial ratios of public and private sector banks and not on the basis of individual banks. Besides, there exist only few studies in the context of India that associates the liquidity, solvency and efficiency positions of the Indian commercial banks with their profitability ratio. Our study attempts to evaluate the financial performance of selected Indian commercial banks for the period from 2012/13 to 2016/17. The study comprises 16 commercial banks, 11 representing public sector and 5 from private sector, and the financial performance of these banks are analysed using the financial ratios. In addition, the study investigates the impact of liquidity, solvency and efficiency on the profitability of the selected public sector banks and private sector banks, respectively, by employing the panel data estimations.

\section{Methodology}

To examine the financial performance of selected Indian commercial banks, the financial ratios of respective banks were used, viz. the liquidity ratio, represented by the quick ratio, current ratio and loans to deposit ratio, the profitability ratio, measured by the return on asset (ROA), return on equity (ROE), price-earnings ratio (P/E ratio), earnings per share (EPS) and net profit margin, the turnover ratio, measured by the total asset turnover ratio (TATR), the solvency ratio, measured by the interest coverage ratio (ICR), and the capital adequacy ratio (CAR). The detailed description on the measurement of financial ratios is provided in Appendix. Considering data availability, the study comprised 16 commercial banks, 11 representing public sector and 5 from private sector. The list of Indian commercial banks selected for the study is shown in Table 1.

The study covers the annual data for the period from 2012/13 to 2016/17 and 
Table 1. List of Indian commercial banks selected for the study.

\begin{tabular}{cccc}
\hline S. No. & $\begin{array}{c}\text { Name of the Selected Public Sector } \\
\text { Commercial Banks }\end{array}$ & S. No. & $\begin{array}{c}\text { Name of the Selected Private Sector } \\
\text { Commercial Banks }\end{array}$ \\
\hline 1. & State Bank of India (SBI) & 1. & Axis Bank \\
2. & Canara Bank & 2. & ICICI Bank \\
3. & Indian Bank & 3. & Kotak Bank \\
4. & Indian Overseas Bank (IOB) & 4. & Karur Vysya Bank (KVB) \\
5. & Bank of India & 5. & \\
6. & Bank of Baroda & \\
7. & Punjab National Bank (PNB) & & \\
8. & Andhra Bank & \\
9. & IDBI Bank & \\
10. & Vijaya Bank & \\
11. & & & \\
\hline
\end{tabular}

the necessary information for this study was obtained from

http://www.moneycontrol.com/ website. The One-way ANOVA has been used to determine whether there is any significant difference between the means of financial ratios of public and private sector banks. Besides, the study employed the panel data estimations, viz. the Fixed Effect and Random Effect models to examine the impact of liquidity, solvency and efficiency on the profitability of the selected public sector banks and private sector banks, respectively. The fixed effect model takes into the firm specific effect and the random effect model consider the time effect.

The fixed effects model is defined as:

$$
\Pi_{i t}=\alpha_{i}+\beta^{\prime} X_{i t}+u_{i t}, i=1, \cdots, N ; t=1, \cdots, T
$$

where, $\Pi_{i t}$ is Return on Asset (ROA) of $i^{\text {th }}$ bank of particular banking industry group in $t^{\text {th }}$ period; $X_{i t}$ is vector of k explanatory variables for $i^{\text {th }}$ bank of particular banking industry group in $t^{\text {th }}$ period, $\beta^{\prime}$ is parameter to be estimated and $u_{i t}$ is error term and assumed IN $\left(0, \sigma^{2}\right) . \alpha_{i}, 1, \cdots, N$ are constant coefficients specific to each bank of respective industry groups. Their presence assumes that differences across the considered banks of respective banking industry groups appear by means of differences in the constant term. These individual coefficients are estimated together with vector of parameters $\beta$.

In the random effects case, the model is defined as:

$$
\Pi_{i t}=\alpha_{i}+\beta^{\prime} X_{i t}+u_{i t}, i=1, \cdots, N ; t=1, \cdots, T
$$

In the random effects model, the $\alpha_{i}$ are treated as random variables rather than fixed constants. The $\alpha_{i}$ are assumed to be independent of the errors $u_{i p}$ i.e. $\alpha_{i} \sim \operatorname{IID}\left(0, \sigma_{\alpha}^{2}\right)$ and $u_{i t} \sim \operatorname{IID}\left(0, \sigma_{u}^{2}\right)$. The $\Pi_{i t}, \beta^{\prime}, X_{i t}$ are defined as earlier. Since $\alpha_{i}$ are random, the errors now are $v_{i t}=\alpha_{i}+u_{i t}$ and the presence of $\alpha_{i}$ produces a correlation among the errors of the same cross-section unit though the 
errors from the different cross-section units are independent. Therefore, the above model is to be estimated by the generalised least squares method [24].

The Hausman specification test is employed to compare the two categories of specifications. A fixed effect model assumes differences in intercepts across groups or time periods, whereas a random effect model explores differences in error variances. The Hausman specification test evaluates the fixed versus random effects under the null hypothesis that the individual effects are uncorrelated with the other regressors in the model [25]. If correlated $\left(\mathrm{H}_{0}\right.$ is rejected), a random effect model produces biased estimators, violating one of the Gauss-Markov assumptions; so a fixed effect model is ideal. Under the null hypothesis, the Hausman statistic is asymptotically distributed as chi-square with $\mathrm{k}$ degrees of freedom.

The general specification of the parameters of the model is as follows:

$$
\mathrm{ROA}_{i t}=a_{i}+b_{1} \mathrm{QR}_{i t}+b_{2} \mathrm{TATR}_{i t}+b_{3} \mathrm{ICR}_{i t}+b_{4} \mathrm{CAR}_{i t}+u_{i t}
$$

where, ROA represents the return on assets of the selected public and private sector banks in India. The explanatory variables, QR, TATR, ICR and CAR denote quick ratio, total asset turnover ratio, interest coverage ratio and capital adequacy ratio, respectively.

\section{Empirical Results}

Table 2 shows the liquidity ratios of selected commercial banks. Among the public sector banks, majority of them are having consistent current ratio during the study period. The current ratio of IDBI is found to be the highest during the year 2016 (i.e. 0.13) which is significantly rose from 0.03 in 2012. The Andhra Bank and the Indian Bank are maintaining a consistent current ratio of 0.03 during the time period. The current ratios of private sector banks are found to be relatively better than the public sector banks. They are able to meet their short term obligations with their current assets. The table results show a leaps and bounds in the quick ratios of public sector banks and private sector banks during the sample period. The liquid assets of the commercial banks keep fluctuating. The ICICI shows an increasing trend, i.e. 10.53 to 16.31 during the years 2012 to 2016.

The ideal loans to deposit ratio of the banks should ranges between 80 and 90 percent depending on the bank's business model [26]. Among the public banks, the SBI and IDBI were able to maintain this ideal position of loans to deposit ratio. All the public banks recorded a decreasing trend during the sample period. Under the private sector banks, the Axis Bank and Yes Bank found to have good record in the case of loans to deposit ratio. In nutshell, the private sector banks maintain a better position in the loans to deposit ratio than the public sector banks.

Table 3 and Table 4 reports the profitability ratios of selected commercial banks. The higher return on asset (ROA) implies that the banks are earning more money on less investment. The public sector banks maintained the highest 
Table 2. Liquidity ratios of selected commercial banks.

\begin{tabular}{|c|c|c|c|c|c|c|c|c|c|c|c|c|c|c|c|}
\hline \multirow{3}{*}{$\begin{array}{c}\text { Name of the } \\
\text { Banks }\end{array}$} & \multicolumn{5}{|c|}{ Current Ratio } & \multicolumn{5}{|c|}{ Quick Ratio } & \multicolumn{5}{|c|}{ Loans to Deposit Ratio } \\
\hline & 2012 & 2013 & 2014 & 2015 & 2016 & 2012 & 2013 & 2014 & 2015 & 2016 & 2012 & 2013 & 2014 & 2015 & 2016 \\
\hline & \multicolumn{15}{|c|}{ Public Sector Banks } \\
\hline SBI & 0.04 & 0.03 & 0.04 & 0.07 & 0.07 & 12.15 & 13.88 & 10.78 & 10.84 & 11.94 & 85.17 & 86.84 & 84.47 & 83.56 & 80.38 \\
\hline Canara Bank & 0.03 & 0.03 & 0.03 & 0.04 & 0.05 & 23.76 & 23.4 & 22.19 & 25 & 25.72 & 69.51 & 69.95 & 70.55 & 68.66 & 68.38 \\
\hline Indian Bank & 0.03 & 0.03 & 0.03 & 0.03 & 0.05 & 19.43 & 21.67 & 22.7 & 25.51 & 24.1 & 74.57 & 74.89 & 74.83 & 73.35 & 71.16 \\
\hline IOB & 0.03 & 0.03 & 0.02 & 0.04 & 0.04 & 30.65 & 30.91 & 33.17 & 25.98 & 26.88 & 79.12 & 78.18 & 73.34 & 70.68 & 69.13 \\
\hline Bank of India & 0.03 & 0.04 & 0.03 & 0.05 & 0.05 & 28.08 & 23.0 & 29.03 & 30.9 & 29.3 & 76.88 & 76.86 & 76.6 & 72.85 & 68.91 \\
\hline Bank of Baroda & 0.02 & 0.02 & 0.02 & 0.05 & 0.04 & 23.9 & 24.05 & 20.78 & 18.27 & 19.38 & 71.68 & 69.54 & 69.54 & 68.13 & 65.24 \\
\hline $\mathrm{PNB}$ & 0.02 & 0.02 & 0.02 & 0.03 & 0.03 & 22.4 & 25.19 & 24.23 & 28.09 & 28.98 & 78.13 & 78.06 & 76.6 & 75.19 & 70.81 \\
\hline Andhra Bank & 0.03 & 0.03 & 0.02 & 0.03 & 0.03 & 36.56 & 33.59 & 28.67 & 29.21 & 23.59 & 79.26 & 77.55 & 78.69 & 77.96 & 72.38 \\
\hline UBI & 0.02 & 0.02 & 0.02 & 0.04 & 0.04 & 31.85 & 30.41 & 28.83 & 36.65 & 35.16 & 11.45 & 10.8 & 10.22 & 10.56 & 11.79 \\
\hline IDBI & 0.03 & 0.03 & 0.03 & 0.13 & 0.13 & 24.82 & 23.11 & 22.95 & 23.35 & 16.93 & 86.12 & 85.12 & 81.93 & 80.73 & 76.13 \\
\hline \multirow[t]{2}{*}{ Vijaya Bank } & 0.03 & 0.03 & 0.03 & 0.05 & 0.06 & 37.98 & 37.18 & 33.80 & 49.9 & 41.03 & 70.90 & 68.35 & 67.11 & 69.78 & 71.01 \\
\hline & \multicolumn{15}{|c|}{ Private Sector Banks } \\
\hline Axis Bank & 0.03 & 0.03 & 0.03 & 0.07 & 0.10 & 20.1 & 18.57 & 20.64 & 25.74 & 17.1 & 77.58 & 80.03 & 84.71 & 91.1 & 92.17 \\
\hline ICICI Bank & 0.09 & 0.09 & 0.06 & 0.13 & 0.12 & 10.53 & 11.31 & 13.81 & 14.97 & 16.31 & 99.25 & 100.71 & 104.72 & 105.08 & 98.69 \\
\hline Kotak Bank & 0.04 & 0.03 & 0.02 & 0.07 & 0.06 & 18.95 & 17.39 & 14.83 & 15.61 & 18.09 & 97.75 & 92.18 & 88.99 & 86.57 & 86.04 \\
\hline KVB & 0.03 & 0.03 & 0.02 & 0.04 & 0.02 & 32.54 & 32.41 & 30.34 & 30.42 & 32.68 & 75.5 & 77.02 & 79.26 & 79.34 & 77.08 \\
\hline Yes Bank & 0.07 & 0.08 & 0.06 & 0.08 & 0.10 & 10.18 & 10.4 & 12.25 & 14.02 & 12.08 & 73.2 & 72.71 & 79.33 & 85.64 & 90.53 \\
\hline
\end{tabular}

Table 3. Profitability ratios of selected commercial banks.

\begin{tabular}{|c|c|c|c|c|c|c|c|c|c|c|c|c|c|c|c|}
\hline \multirow{3}{*}{$\begin{array}{c}\text { Name of the } \\
\text { Banks }\end{array}$} & \multicolumn{5}{|c|}{ Return on Assets (\%) } & \multicolumn{5}{|c|}{ Return on Equity (\%) } & \multicolumn{5}{|c|}{ Earnings Per Share (Rs.) } \\
\hline & 2012 & 2013 & 2014 & 2015 & 2016 & 2012 & 2013 & 2014 & 2015 & 2016 & 2012 & 2013 & 2014 & 2015 & 2016 \\
\hline & \multicolumn{15}{|c|}{ Public Sector Banks } \\
\hline SBI & 0.9 & 0.61 & 0.64 & 0.44 & 0.39 & 14.26 & 9.2 & 10.2 & 6.89 & 6.69 & 210.06 & 156.76 & 17.55 & 12.98 & 13.43 \\
\hline Canara Bank & 0.7 & 0.5 & 0.49 & -0.51 & 0.19 & 12.57 & 10.1 & 10.21 & 0 & 3.96 & 64.83 & 54.48 & 58.59 & -53.61 & 20.63 \\
\hline Indian Bank & 0.97 & 0.61 & 0.52 & 0.34 & 0.64 & 15.14 & 10.04 & 8 & 5.27 & 9.72 & 35.8 & 26.07 & 21.62 & 14.81 & 29.27 \\
\hline IOB & 0.23 & 0.21 & -0.15 & -1.05 & -1.38 & -0.55 & 4.19 & 0 & 0 & 0 & 6.14 & 6.05 & -3.68 & -19.86 & -15.78 \\
\hline Bank of India & 0.6 & 0.47 & 0.27 & -0.99 & -0.24 & 11.49 & 9.12 & 5.43 & 0 & 0 & 47.79 & 44.74 & 26.57 & -83.01 & -15.72 \\
\hline Bank of Baroda & 0.81 & 0.68 & 0.47 & -0.8 & 0.19 & 14.01 & 12.61 & 8.53 & 0 & 3.43 & 109 & 107 & 16 & -23.89 & 6 \\
\hline PNB & 0.99 & 0.6 & 0.5 & -0.59 & 0.18 & 15.19 & 9.69 & 8.12 & 0 & 3.47 & 139.52 & 93.91 & 16.91 & -20.82 & 6.45 \\
\hline Andhra Bank & 9.98 & 3.04 & 3.9 & 3.06 & 0.96 & 15.27 & 4.98 & 6.34 & 4.91 & 1.53 & 23.04 & 7.67 & 10.82 & 8.6 & 2.56 \\
\hline UBI & 0.69 & 0.47 & 0.46 & 0.33 & 0.12 & 13.75 & 10.03 & 9.71 & 6.65 & 2.36 & 38.93 & 27.99 & 28.05 & 20.42 & 8.08 \\
\hline IDBI & 0.58 & 0.34 & 0.24 & -0.97 & -1.42 & 9.66 & 5.11 & 3.85 & 0 & 0 & 14.7 & 8 & 5.45 & -21.77 & -25.05 \\
\hline \multirow[t]{2}{*}{ Vijaya Bank } & 0.52 & 0.30 & 0.30 & 0.26 & 0.48 & 14.29 & 7.37 & 7.41 & 5.84 & 10.25 & 9.41 & 7.64 & 5.11 & 4.44 & 7.57 \\
\hline & \multicolumn{15}{|c|}{ Private Sector Banks } \\
\hline Axis Bank & 1.46 & 1.02 & 0.94 & 0.36 & 0.3 & 15.64 & 16.26 & 16.46 & 15.46 & 6.59 & 119.67 & 132.56 & 31 & 34.59 & 15.4 \\
\hline ICICI Bank & 1.55 & 1.64 & 1.72 & 1.34 & 1.26 & 12.48 & 13.39 & 13.89 & 11.19 & 10.11 & 71.93 & 84.65 & 19.13 & 16.65 & 16.77 \\
\hline Kotak Bank & 1.62 & 1.71 & 1.76 & 1.08 & 1.58 & 14.37 & 12.23 & 13.19 & 8.72 & 12.35 & 18.31 & 19.62 & 24.2 & 11.42 & 18.57 \\
\hline KVB & 1.17 & 0.83 & 0.87 & 0.98 & 0.98 & 17.83 & 12.91 & 10.93 & 12.41 & 12.03 & 51.35 & 40.08 & 39.86 & 46.59 & 9.95 \\
\hline Yes Bank & 1.31 & 1.48 & 1.47 & 1.53 & 1.54 & 22.39 & 22.71 & 17.16 & 18.41 & 15.09 & 36.53 & 44.92 & 49.34 & 60.62 & 78.89 \\
\hline
\end{tabular}


Table 4. Profitability ratios of selected commercial banks.

\begin{tabular}{|c|c|c|c|c|c|c|c|c|c|c|}
\hline \multirow{3}{*}{$\begin{array}{c}\text { Name of the } \\
\text { Banks }\end{array}$} & \multicolumn{5}{|c|}{ Price Earnings Ratio } & \multicolumn{5}{|c|}{ Net Profit Margin (\%) } \\
\hline & \multicolumn{10}{|c|}{ Public Sector Banks } \\
\hline & 2012 & 2013 & 2014 & 2015 & 2016 & 2012 & 2013 & 2014 & 2015 & 2016 \\
\hline SBI & 9.77 & 12.18 & 15.62 & 15.04 & 21.47 & 11.78 & 7.98 & 8.59 & 6.07 & 5.97 \\
\hline Canara Bank & 6.14 & 5.06 & 6.54 & -3.4 & 14.74 & 8.42 & 6.16 & 6.17 & -6.38 & 2.71 \\
\hline Indian Bank & 4.6 & 4.45 & 7.96 & 6.69 & 9.21 & 11.38 & 7.6 & 6.34 & 4.37 & 8.76 \\
\hline IOB & 10.7 & 8.6 & -11.63 & -1.51 & -1.71 & 2.74 & 2.65 & -1.89 & -12.31 & -17.32 \\
\hline Bank of India & 6.33 & 5.21 & 7.78 & -1.21 & -8.88 & 8.61 & 7.19 & 3.93 & -14.56 & -3.96 \\
\hline Bank of Baroda & 5.98 & 7.04 & 10.65 & -6.4 & 28.08 & 12.73 & 11.66 & 7.91 & -12.24 & 3.27 \\
\hline PNB & 5.15 & 8.03 & 8.99 & -3.91 & 23.15 & 11.33 & 7.73 & 6.61 & -8.38 & 2.8 \\
\hline Andhra Bank & 4.09 & 8.47 & 7.47 & 6.43 & 22.75 & 9.98 & 3.04 & 3.9 & 3.06 & 0.96 \\
\hline UBI & 5.66 & 5.07 & 5.78 & 6.14 & 18.76 & 8.58 & 5.77 & 5.55 & 4.19 & 1.69 \\
\hline IDBI & 5.54 & 8.16 & 13.34 & -3.33 & -2.99 & 7.5 & 4.21 & 3.1 & -13.06 & -18.56 \\
\hline \multirow[t]{2}{*}{ Vijaya Bank } & 5.63 & 5.19 & 9.2 & 7.25 & 8.91 & 6.46 & 3.88 & 3.58 & 3.15 & 6.06 \\
\hline & \multicolumn{10}{|c|}{ Private Sector Banks } \\
\hline Axis Bank & 10.85 & 10.77 & 18.38 & 13 & 31.87 & 19.05 & 20.29 & 20.73 & 20.06 & 8.26 \\
\hline ICICI Bank & 12.59 & 13.23 & 15.37 & 12.09 & 14.98 & 20.77 & 22.2 & 22.76 & 18.44 & 18.09 \\
\hline Kotak Bank & 17.34 & 19.2 & 28.15 & 59.38 & 47.01 & 16.91 & 17.13 & 19.19 & 12.75 & 19.27 \\
\hline KVB & 8.74 & 8.91 & 13.67 & 95.33 & 112.31 & 12.97 & 8.39 & 8.6 & 10.42 & 10.77 \\
\hline Yes Bank & 11.78 & 9.42 & 17.21 & 14.09 & 19.72 & 15.68 & 16.2 & 17.32 & 18.76 & 20.27 \\
\hline
\end{tabular}

ROA during the year 2012 and thereafter they will be steep decrease in their ROA. It is observed from the table that the private banks have a better ROA than public banks. Their ROA is greater than one percent in the majority of the banks during the sample period.

On the other side, the return on equity (ROE) measures a bank's profitability by revealing how much profit a bank generates with the money shareholders have invested. The ROA have been decreasing over the period for all the public banks. The private banks provided better ROE than the public banks with an average of 14.16 percent.

The earnings per share (EPS) is the portion of a bank's profit allocated to each outstanding share of common stock. EPS can be negative if the bank is losing money. From the Table 3, it is clear that the majority of the public sector banks having negative EPS during the sample period. The reasons may include non-performing assets, reinvestment in a bank's operations, debt reduction and poor earnings. Most importantly, the commercial banks may decide to reinvest its profits in its development of new products or into core business assets. In this case, although it retains some of its earnings, the action does not signal the bank is in weak financial health. This reinvestment may lead to a higher EPS in the future. The private banks have given better EPS to its shareholders during the time period, although 
their EPS recorded the decreasing trend. YES Bank is an exception in which it has increased its EPS gradually from 36.53 to 78.89 .

A high net profit margin shows that a bank can convert their sales into profits. From Table 4, it is clear that the majority of the public banks show negative net profit margin and they are not able to convert their sales into profits. Another reason might be due to the expansion activities of these banks. The IOB and IDBI have shown a drastic decrease in the Net profit margin. The private banks experienced leaps and bounds in its profit margins. However, they are earning much better than their public counterparts from its sales. The ICICI bank earned 22.76 percent net profit margin in 2014 which was the highest. Generally, the banks with high $\mathrm{P} / \mathrm{E}$ ratio suggest that investors are expecting higher earnings growth in the future compared to the banks with a lower P/E. The Table 4 shows that majority of the public sector banks has negative $\mathrm{P} / \mathrm{E}$ ratio due to their negative EPS. Besides, the private banks found to have consistent P/E ratio and they are relatively better than the public sector banks during the study period.

Table 5 shows the turnover ratio of selected commercial banks. The asset turnover ratio can often be used as an indicator of the efficiency with which a bank is deploying its assets in generating revenue. The public banks have maintained a steady asset turnover ratio during the sample period. The private sector banks also had a consistent asset turnover ratio.

Table 5. Turnover ratio of selected commercial banks.

\begin{tabular}{|c|c|c|c|c|c|}
\hline \multirow{2}{*}{ Name of the Banks } & \multicolumn{5}{|c|}{ Total Assets Turnover Ratio } \\
\hline & 2012 & 2013 & 2014 & 2015 & 2016 \\
\hline \multicolumn{6}{|c|}{ Public Sector Banks } \\
\hline SBI & 0.08 & 0.08 & 0.08 & 0.08 & 0.07 \\
\hline Canara Bank & 0.09 & 0.09 & 0.09 & 0.08 & 0.07 \\
\hline Indian Bank & 0.09 & 0.09 & 0.08 & 0.08 & 0.08 \\
\hline IOB & 0.18 & 0.11 & 0.09 & 0.08 & 0.08 \\
\hline Bank of India & 0.08 & 0.07 & 0.07 & 0.07 & 0.06 \\
\hline Bank of Baroda & 0.07 & 0.06 & 0.06 & 0.06 & 0.06 \\
\hline PNB & 0.09 & 0.08 & 0.08 & 0.07 & 0.07 \\
\hline Andhra Bank & 0.1 & 0.09 & 0.09 & 0.09 & 0.09 \\
\hline UBI & 0.09 & 0.09 & 0.09 & 0.08 & 0.08 \\
\hline IDBI & 0.08 & 0.08 & 0.08 & 0.08 & 0.08 \\
\hline Vijaya Bank & 0.09 & 0.09 & 0.09 & 0.08 & 0.08 \\
\hline \multicolumn{6}{|c|}{ Private Sector Banks } \\
\hline Axis Bank & 0.09 & 0.08 & 0.08 & 0.08 & 0.08 \\
\hline ICICI Bank & 0.08 & 0.08 & 0.08 & 0.08 & 0.07 \\
\hline Kotak Bank & 0.11 & 0.10 & 0.10 & 0.11 & 0.09 \\
\hline KVB & 0.10 & 0.10 & 0.10 & 0.1 & 0.09 \\
\hline Yes Bank & 0.10 & 0.10 & 0.09 & 0.09 & 0.09 \\
\hline
\end{tabular}


Table 6 depicts the solvency ratio of selected commercial banks. The solvency ratio is represented by the interest coverage ratio. It measures the margin of safety a bank has for paying interest during a given period. The higher ratio indicates the better position of the bank to meet its interest obligations. The Canara Bank, Bank of India, Bank of Baroda, PNB, IOB and IDBI have negative interest coverage ratio which shows that their current earnings are insufficient to service the company's current outstanding debt. The remaining public banks are also in a difficult position as their values are well below one. The private banks have relatively better interest coverage ratio than the public banks, despite the fact that their ratios lie below one.

Table 7 provides the capital adequacy ratio of selected commercial banks. The capital adequacy ratio (CAR) is a measure of a bank's capital. It is expressed as a percentage of a bank's risk weighted credit exposures. Minimum capital adequacy ratios are critical to make sure that banks have enough cushions to absorb a reasonable amount of losses before they become insolvent and consequently lose depositors' funds. The Basel III norms stipulated a capital to risk weighted assets of 8 percent. However, as per RBI norms, Indian scheduled commercial banks are required to maintain a CAR of 9 percent while Indian public sector banks are emphasized to maintain a CAR of 12 percent [27]. It is evident from

Table 6. Solvency ratio of selected commercial banks.

\begin{tabular}{|c|c|c|c|c|c|}
\hline \multirow{2}{*}{ Name of the Banks } & \multicolumn{5}{|c|}{ Interest Coverage Ratio } \\
\hline & 2012 & 2013 & 2014 & 2015 & 2016 \\
\hline \multicolumn{6}{|c|}{ Public Sector Banks } \\
\hline SBI & 0.26 & 0.19 & 0.20 & 0.13 & 0.13 \\
\hline Canara Bank & 0.14 & 0.10 & 0.10 & -0.09 & 0.05 \\
\hline Indian Bank & 0.19 & 0.14 & 0.13 & 0.08 & 0.16 \\
\hline IOB & 0.05 & 0.05 & 0.01 & -0.21 & -0.23 \\
\hline Bank of India & 0.13 & 0.13 & 0.06 & -0.26 & -0.09 \\
\hline Bank of Baroda & 0.20 & 0.20 & 0.18 & -0.21 & 0.09 \\
\hline PNB & 0.24 & 0.17 & 0.13 & -0.18 & 0.06 \\
\hline Andhra Bank & 0.19 & 0.07 & 0.17 & 0.08 & 0.03 \\
\hline UBI & 0.17 & 0.10 & 0.12 & 0.07 & 0.01 \\
\hline IDBI & 0.13 & 0.08 & 0.06 & -0.23 & -0.39 \\
\hline Vijaya Bank & 0.08 & 0.05 & 0.04 & 0.02 & 0.10 \\
\hline \multicolumn{6}{|c|}{ Private Sector Banks } \\
\hline Axis Bank & 0.38 & 0.32 & 0.31 & 0.12 & 0.10 \\
\hline ICICI Bank & 0.43 & 0.50 & 0.52 & 0.39 & 0.35 \\
\hline Kotak Bank & 0.41 & 0.45 & 0.52 & 0.33 & 0.54 \\
\hline KVB & 0.24 & 0.10 & 0.12 & 0.25 & 0.25 \\
\hline Yes Bank & 0.32 & 0.32 & 0.36 & 0.42 & 0.47 \\
\hline
\end{tabular}


Table 7. Capital adequacy ratio of selected commercial banks.

\begin{tabular}{|c|c|c|c|c|c|}
\hline Name of the Banks & 2012 & 2013 & 2014 & 2015 & 2016 \\
\hline \multicolumn{6}{|c|}{ Public Sector Banks } \\
\hline SBI & 12.92 & 12.96 & 12 & 13.12 & 13.11 \\
\hline Canara Bank & 12.4 & 10.63 & 10.56 & 11.08 & 12.86 \\
\hline Indian Bank & 13.08 & 13.10 & 12.86 & 13.20 & 13.64 \\
\hline $\mathrm{IOB}$ & 11.85 & 10.78 & 10.11 & 9.66 & 10.50 \\
\hline Bank of India & 11.02 & 9.97 & 10.73 & 12.01 & 12.14 \\
\hline Bank of Baroda & 13.3 & 12.28 & 12.6 & 13.17 & 13.17 \\
\hline PNB & 12.72 & 12.11 & 12.89 & 11.28 & 11.66 \\
\hline Andhra Bank & 11.76 & 11.18 & 10.63 & 11.58 & 12.38 \\
\hline UBI & 11.85 & 11.45 & 10.80 & 10.22 & 10.56 \\
\hline IDBI & 13.13 & 11.68 & 11.76 & 11.67 & 10.70 \\
\hline Vijaya Bank & 11.32 & 10.97 & 11.43 & 12.58 & 12.73 \\
\hline \multicolumn{6}{|c|}{ Private Sector Banks } \\
\hline Axis Bank & 17 & 16.07 & 15.09 & 15.29 & 14.95 \\
\hline ICICI Bank & 18.74 & 17.7 & 17.02 & 16.64 & 17.39 \\
\hline Kotak Bank & 16.05 & 18.83 & 17.17 & 16.34 & 16.77 \\
\hline KVB & 14.41 & 12.6 & 14.62 & 12.17 & 12.54 \\
\hline Yes Bank & 18.30 & 14.40 & 15.60 & 16.50 & 17.07 \\
\hline
\end{tabular}

the table that the Indian public sector banks except the SBI, Indian Bank and Bank of Baroda had experienced a poor performance in maintaining the prescribed limit of CAR as per RBI norms. While the private banks show healthy capital adequacy ratios during the sample period.

For determining whether there is any significant mean difference between the financial ratios of selected public sector and private sector banks, we applied one-way ANOVA test and the results are presented in Table 8. It is clear from the table results that the F-statistics for the financial ratios except Capital Adequacy Ratio (CAR) are found to be statistically significant. Hence the null hypothesis of no mean differences in the respective financial ratios of selected private and public sector banks is rejected and alternative hypothesis is accepted. Therefore, the financial performance of public and private bank groups regarding these ratios is different during the study period.

In order to examine the impact of liquidity, solvency and efficiency on the profitability of selected commercial banks, the fixed effect (FE) model and random effect (RE) model were employed. Table 9 presents the fixed effect and random effect estimates for the selected public sector banks. First and foremost, as far as selection of an appropriate model is concerned, the table provides the results of Hausman specification test (FE versus RE) which are applied to specify an appropriate model for our panel data. Under the panel data estimations, the 
Table 8. One-way ANOVA results for the financial ratios of the selected commercial banks.

\begin{tabular}{|c|c|c|c|c|c|c|}
\hline \multicolumn{7}{|c|}{ Liquidity Ratios } \\
\hline \multirow[t]{2}{*}{ Variables } & & $\begin{array}{l}\text { Sum of } \\
\text { Squares }\end{array}$ & $\mathrm{df}$ & $\begin{array}{l}\text { Mean } \\
\text { Square }\end{array}$ & F Statistics & $\begin{array}{l}\text { Prob. } \\
\text { Value }\end{array}$ \\
\hline & Between Groups & 0.009 & 1 & 0.009 & & \\
\hline \multirow[t]{3}{*}{$\mathrm{CR}$} & Within Groups & 0.051 & 78 & 0.001 & $13.350^{*}$ & 0.000 \\
\hline & Total & 0.060 & 79 & & & \\
\hline & Between Groups & 932.034 & 1 & 932.034 & & \\
\hline \multirow[t]{3}{*}{ QR } & Within Groups & 4455.366 & 78 & 57.120 & $16.317^{\star}$ & 0.000 \\
\hline & Total & 5387.399 & 79 & & & \\
\hline & Between Groups & 5521.779 & 1 & 5521.779 & & \\
\hline \multirow[t]{4}{*}{ LDR } & Within Groups & $22,472.899$ & 78 & 288.114 & $19.165^{\star}$ & 0.000 \\
\hline & Total & $27,994.679$ & 79 & & & \\
\hline & & Profitabil & Ratio & & & \\
\hline & Between Groups & 7.875 & 1 & 7.875 & & \\
\hline \multirow[t]{3}{*}{$\mathrm{ROA}$} & Within Groups & 138.854 & 78 & 1.780 & $4.424^{\star *}$ & 0.039 \\
\hline & Total & 146.730 & 79 & & & \\
\hline & Between Groups & 922.549 & 1 & 922.549 & & \\
\hline \multirow[t]{3}{*}{$\mathrm{ROE}$} & Within Groups & 1595.199 & 78 & 20.451 & $45.110^{*}$ & 0.000 \\
\hline & Total & 2517.749 & 79 & & & \\
\hline & Between Groups & 6694.575 & 1 & 6694.575 & & \\
\hline \multirow[t]{3}{*}{ EPS } & Within Groups & $152,652.252$ & 78 & 1957.080 & $3.421^{\star * *}$ & 0.068 \\
\hline & Total & $159,346.827$ & 79 & & & \\
\hline & Between Groups & 5840.041 & 1 & 5840.041 & & \\
\hline \multirow[t]{3}{*}{ PER } & Within Groups & $20,005.479$ & 78 & 256.481 & $22.770^{*}$ & 0.000 \\
\hline & Total & $25,845.520$ & 79 & & & \\
\hline & Between Groups & 3163.345 & 1 & 3163.345 & & \\
\hline \multirow[t]{2}{*}{ NPM } & Within Groups & 3509.930 & 78 & 44.999 & $70.298^{*}$ & 0.000 \\
\hline & Total & 6673.275 & 79 & & & \\
\hline \multicolumn{7}{|c|}{ Turnover Ratio } \\
\hline \multirow{3}{*}{ TATR } & Between Groups & 0.001 & 1 & 0.001 & & \\
\hline & Within Groups & 0.018 & 78 & 0.000 & $5.011^{\star *}$ & 0.028 \\
\hline & Total & 0.019 & 79 & & & \\
\hline \multicolumn{7}{|c|}{ Solvency Ratio } \\
\hline \multirow{3}{*}{ ICR } & Between Groups & 1.341 & 1 & 1.341 & & \\
\hline & Within Groups & 1.456 & 78 & 0.019 & $71.857^{\star}$ & 0.000 \\
\hline & Total & 2.797 & 79 & & & \\
\hline \multicolumn{7}{|c|}{ Capital Adequacy Ratio } \\
\hline \multirow{3}{*}{ CAR } & Between Groups & 69.701 & 1 & 69.701 & & \\
\hline & Within Groups & $20,232.931$ & 78 & 259.397 & 0.269 & 0.606 \\
\hline & Total & $20,302.632$ & 79 & & & \\
\hline
\end{tabular}

Notes: ${ }^{*}, * *$ and ${ }^{* *}$ denote the significance at the one, five and ten per cent level, respectively. 
Table 9. Fixed effect and random effect estimates for the selected public sector banks.

\begin{tabular}{ccccccc}
\hline \multicolumn{7}{c}{ Dependent Variable: ROA } \\
\hline Variables & $\begin{array}{c}\text { Fixed Effect } \\
\text { (FE) }\end{array}$ & t-statistics & $\begin{array}{l}\text { Prob. } \\
\text { Value }\end{array}$ & $\begin{array}{c}\text { Random Effect } \\
(\mathbf{R E})\end{array}$ & Z-statistics & $\begin{array}{c}\text { Prob. } \\
\text { Value }\end{array}$ \\
\hline QR & 0.1189 & $2.77^{*}$ & 0.008 & 0.0856 & $2.58^{*}$ & 0.010 \\
TATR & 12.011 & 1.10 & 0.278 & 8.3932 & 0.84 & 0.399 \\
ICR & 4.3919 & $3.74^{\star}$ & 0.001 & 4.7052 & $4.26^{*}$ & 0.000 \\
CAR & -0.1862 & -0.98 & 0.332 & -0.0161 & -0.81 & 0.419 \\
C & -0.4466 & -0.14 & 0.892 & -2.3526 & $-1.91^{* * *}$ & 0.056 \\
Hausman test & & - & & & $8.43^{*}(0.000)$ & \\
\hline
\end{tabular}

Notes: ${ }^{*}$ and ${ }^{* *}$ denote the significance at the one and ten per cent level, respectively. ()-values in the brackets indicate probability value.

dependent variable ROA is regressed with independent variables, viz. QR, TATR, ICR and CAR. The null hypothesis for Hausman test is that there is no correlation between unique errors and the regressors. It implies that both FE and RE estimates are unbiased, but RE model is more efficient than FE model. So if null fails to be rejected, then RE model would be appropriate. The Hausman test statistics under the RE model found to be statistically significant at one percent level, implying that RE model can be rejected and hence FE model is preferred over RE model. It can be concluded that the FE model is considered better than RE model, and is the best panel data approach for explaining the ROA regression results. The empirical findings from the fixed effect model reveal that the quick ratio $(\mathrm{QR})$ is found to be positive and statistically significant at one percent level, implying that one unit change in quick ratio will leads to 0.118 unit change in return on asset (ROA). Besides, the interest coverage ratio (ICR) is found to be positive and statistically significant at one percent level, implying that one unit change in interest coverage ratio will leads to 4.391 unit change in return on asset (ROA). It can be suggested that the liquidity and solvency, represented by the quick ratio and interest coverage ratio respectively, plays a significant role in determining the profitability of the selected public sector banks.

Table 10 exhibits the fixed effect and random effect estimates for the selected private sector banks. The Hausman test statistics under the RE model found to be statistically insignificant, implying that RE model cannot be rejected and hence RE model is preferred over FE model. The empirical findings from the random effect model reveal that the total asset turnover ratio (TATR) is found to be positive and statistically significant at one percent level, implying that one unit change in quick ratio will leads to 9.056 unit change in return on asset (ROA). Besides, the interest coverage ratio (ICR) is found to be positive and statistically significant at one percent level, implying that one unit change in interest coverage ratio will leads to 2.773 unit change in return on asset (ROA). The results confirmed that the turnover and solvency, represented by the total asset 
Table 10. Fixed effect and random effect estimates for the selected private sector banks.

\begin{tabular}{ccccccc}
\hline \multicolumn{7}{c}{ Dependent Variable: ROA } \\
\hline Variables & $\begin{array}{c}\text { Fixed Effect } \\
(\mathrm{FE})\end{array}$ & t-Statistics & $\begin{array}{c}\text { Prob. } \\
\text { Value }\end{array}$ & $\begin{array}{c}\text { Random Effect } \\
(\mathrm{RE})\end{array}$ & Z-Statistics & $\begin{array}{c}\text { Prob. } \\
\text { Value }\end{array}$ \\
\hline QR & -0.0047 & -1.37 & 0.190 & -0.0032 & -0.76 & 0.446 \\
TATR & 15.473 & $3.10^{*}$ & 0.007 & 9.0567 & $3.01^{*}$ & 0.003 \\
ICR & 2.7737 & $8.91^{*}$ & 0.000 & 2.7249 & $8.47^{*}$ & 0.000 \\
CAR & 0.0213 & 0.86 & 0.403 & 0.0046 & 0.19 & 0.847 \\
C & -1.3421 & $-2.41^{* *}$ & 0.028 & -0.5040 & -1.07 & 0.285 \\
Hausman test & & - & & & $1.72(0.7869)$ & \\
\hline
\end{tabular}

Notes: ${ }^{*}$ and ${ }^{*}$ denote the significance at the one and five per cent level, respectively. ()-values in the brackets indicate Probability value.

turnover ratio and interest coverage ratio respectively, plays a significant role in determining the profitability of the selected private sector banks.

\section{Conclusions}

The present study attempts to evaluate the financial performance of selected Indian commercial banks for the period from 2012/13 to 2016/17. The study comprises 16 commercial banks, 11 representing public sector and 5 from private sector, and the financial performances of these banks are analysed using the financial ratios. The liquidity ratio, represented by the current ratio and loans to deposit ratio, are found to be relatively better in the case of private sector banks. However, the quick ratios of private and public sector banks show leaps and bounds throughout the study period. With respect to profitability ratio, it is observed that the private banks have a better ROA, ROE, P/E ratio and EPS than the public banks. However, the private banks experienced leaps and bounds in its profit margins and the public sector banks have maintained a steady asset turnover ratio throughout the study period. The private banks are found to be relatively better than the public sector banks with respect to solvency ratio and capital adequacy ratio.

The study shows that the financial performances of selected private sector banks are relatively better than the public sector banks throughout the sample period. In addition, the study examines the impact of liquidity, solvency and efficiency on the profitability of the selected Indian commercial banks by employing the panel data estimations, viz. the Fixed Effect and Random Effect models. The empirical results from the panel data estimations revealed that the liquidity ratio and solvency ratio, and the turnover ratio and solvency ratio are found to have positive and significant impact on the profitability of selected public sector and private sector banks, respectively, bearing testimony to the fact that profitability is a function of those ratios.

Due to immense competition, the policy changes and the operational environment in which the Indian banking system is presently operating, there has been 
an increased focus on liquidity, solvency, operational efficiency and profitability among the selected private sector banks. Most of the selected public sector banks have registered a significant improvement in their asset turnover ratio and profit margins, but the selected private sector banks continue to have still better profitability, liquidity, solvency and healthy capital adequacy ratios.

Most importantly, the increasing level of non-performing assets (NPAs) is the most challenging task faced by the Indian banking system, especially public sector banks, and the same need to be addressed aptly. More Debt Recovery Tribunals (DRTs) should be established and no loan waivers under any circumstances to be undertaken. Besides, the vibrant policy measures have to be implemented to enhance the operational efficiencies of the selected public sector banks to merge the large number of unremunerative or loss making branches. Branches with low productivity and excess staffing and old traditional methods of operations have to be replaced by strategic moves to gain competitive advantage. It is suggested that the public sector banks should take necessary steps to enhance their liquidity and solvency position to amplify their profitability. The private banks should escalate their turnover and solvency position to augment their profits.

\section{Limitation of the Study}

The analysis and derived conclusions are based on the secondary data sources for the limited period. Besides, the present study is confined to bank-specific determinants of profitability (liquidity ratio, profitability ratio, turnover ratio, solvency ratio and capital adequacy ratio) and the external factors such as gross domestic product, inflation, stock market capitalization, etc. are not taken into consideration. Hence there is scope for further research pertaining to the subject with the inclusion of external factors in the model. Also the study can be extended for non-banking financial companies (NBFCs).

\section{References}

[1] Hirigoyen, G. (1985) Rentabilité et solvabilité. Direction et Gestion, 3, 13-26.

[2] Haque, A. (2014) Comparison of Financial Performance of Commercial Banks: A Case Study in the Context of India (2009-2013). Journal of Finance and Bank Management, 2, 1-14.

[3] Goel, U., Chadha, S. and Sharma, A.K. (2015) Operating Liquidity and Financial Leverage: Evidences from Indian Machinery Industry. Procedia-Social and Behavioral Sciences, 189, 344-350. https://doi.org/10.1016/j.sbspro.2015.03.230

[4] Calomiris, C.W. and Kahn, C.M. (1991) The Role of Demandable Debt in Structuring Optimal Banking Arrangements. American Economic Review, 81, 497-513.

[5] Holmstrom, B. and Tirole, J. (1997) Financial Intermediation, Loanable Funds, and the Real Sector. The Quarterly Journal of Economics, 112, 663-691. https://doi.org/10.1162/003355397555316

[6] Samad, A. (2004) Performance of Interest-Free Islamic Banks vis-à-vis Interest-Based Conventional Banks of Bahrain. IIUM Journal of Economics and Management, 12, $1-15$. 
[7] Tarawneh, M, (2006) A Comparison of Financial Performance in the Banking Sector: Some Evidence from Omani Commercial Banks. International Research Journal of Finance and Economics, 3, 101-112.

[8] Kumbirai, M. and Webb, R. (2010) A financial Ratio Analysis of Commercial Bank Performance in South Africa. African Review of Economics and Finance, 2, 30-53.

[9] Ahmed, A.A. (2011) Financial Performance Evaluation of Some Selected Jordanian Commercial Banks. International Research Journal of Finance and Economics, 68, 50-63.

[10] Alkhatib, A. and Harasheh, M. (2012) Financial Performance of Palestinian Commercial Banks. International Journal of Business and Social Science, 3, 175-184.

[11] Doğan, M. (2013) Comparison of Financial Performances of Domestic and Foreign Banks: The Case of Turkey. International Journal of Business and Social Science, 4, 233-240.

[12] Haque, S. (2013) The Performance Analysis of Private Conventional Banks: A Case Study of Bangladesh. IOSR Journal of Business and Management, 2, 19-25. https://doi.org/10.9790/487X-1211925

[13] Karim, R.A. and Alam, T. (2013) An Evaluation of Financial Performance of Private Commercial Banks in Bangladesh: Ratio Analysis. Journal of Business Studies Quarterly, 5, 65-77.

[14] Ongore, V.O. and Kusa, G.B. (2013) Determinants of Financial Performance of Commercial Banks in Kenya. International Journal of Economics and Financial Issues, 3, 237-252.

[15] Bodla, B.S. and Verma, R. (2006) Determinants of Profitability of Banks in India: $A$ Multivariate Analysis. Journal of Service Research, 6, 75-89.

[16] Tabak, B.M. and Tecles, P.L. (2010) Estimating a Bayesian Stochastic Frontier for the Indian Banking System. International Journal of Production Economics, 125, 96-110. https://doi.org/10.1016/j.ijpe.2010.01.008

[17] Maheshwari, N. and Agarwal, N. (2013) Evaluating Financial Performance of SBI through Financial Ratios. Indian Journal of Finance, 7, 34-44.

[18] Makkar, A. and Singh, S. (2013) Analysis of the Financial Performance of Indian Commercial Banks: A Comparative Study. Indian Journal of Finance, 7, 41-49.

[19] Molyneux, P. and Thornton, J. (1992) Determinants of European Bank Profitability: A Note. Journal of Banking and Finance, 16, 1173-1180. https://doi.org/10.1016/0378-4266(92)90065-8

[20] Srinivasan, P. and Saminathan, Y.P. (2016) A Camel Model Analysis of Public, Private and Foreign Sector Banks in India. Pacific Business Review International, 8, 45-57.

[21] Sahota, S. and Dhiman, B. (2017) Relative Performance Analysis of Scheduled Commercial Banks in India: A CAMEL Model Approach. Indian Journal of Finance, 11, 40-57. https://doi.org/10.17010/ijf/2017/v11i5/114251

[22] Tatuskar, S. (2010) A Study of Financial Performance of Select Indian Scheduled Commercial Banks Using CAMELS Methodology for 2006-2010. International Journal of Research in Commerce and Management, 1, 105-121.

[23] Nagarkar, J.J. (2015) Analysis of Financial Performance of Banks in India. Annual Research Journal of Symbiosis Centre for Management Studies, 3, 26-37.

[24] Maddala, G.S. (2005) Introduction to Econometrics. 3rd Edition, John Wiley \& Sons, Ltd. 
[25] Hausman, J.A. (1978) Specification Tests in Econometrics. Econometrica, 46, 1251-1271. https://doi.org/10.2307/1913827

[26] Forbes (2015) Shrinking Loan-to-Deposit Ratios Remain Cause for Concern among Banks.

https://www.forbes.com/sites/greatspeculations/2015/03/10/shrinking-loan-to-depo sit-ratios-remain-cause-for-concern-among-banks $/+\& \mathrm{~cd}=4 \& \mathrm{hl}=\mathrm{en} \& \mathrm{ct}=\mathrm{clnk} \& \mathrm{gl}=\mathrm{in}$

[27] Fatima, N. (2014) Capital Adequacy: A Financial Soundness Indicator for Banks. Global Journal of Finance and Management, 6, 771-776. 


\section{Appendix}

S. No. Financial Ratio

The current ratio is a liquidity ratio that evaluates a bank's capacity to

1. Current Ratio pay short-term and long-term obligations. A ratio below 1 show that bank's liabilities are greater than its assets and suggest that the bank not able to pay off its obligations.

The quick ratio is also a liquidity ratio that represents the bank's

2. Quick Ratio short-term liquidity. It evaluates the bank's ability to meet its short-term obligations with its most liquid assets.

3. Loan to Deposit Ratio

The loan-to-deposit ratio (LTD) is also a commonly used statistic or assessing a bank's liquidity by dividing the bank's total loans by its total deposits.

4. Return on
Assets

Return on assets (ROA) is a profitability ratio that indicates how profitable a bank is relative to its total assets.

5. Return on
Equity

Return on equity is commonly used profitability ratio that measures a bank's profitability by revealing how much profit a bank generates with the money shareholders have invested.

6. Earnings Per Share

Earnings Per Share (EPS) measures the fraction of a bank's profit allocated to each outstanding share of common stock. EPS acts as an indicator of a bank's profitability.

7. Net

Profit Margin

Another measure of profitability ratio is the net profit margin measured by the ratio of net profits to revenues for a bank.

Asset turnover ratio is the ratio of the value of a bank's sales

Total Asset Turnover Ratio or revenues generated relative to the value of its assets. The Asset Turnover ratio can often be used as an indicator of the efficiency with which a bank is deploying its assets in generating revenue.

The price-earnings ratio ( $\mathrm{P} / \mathrm{E}$ ratio) is the ratio for valuing a bank Price that measures its current share price relative to its per-share earnings.

9. Earnings Ratio A high $\mathrm{P} / \mathrm{E}$ suggests that investors are expecting higher earnings growth in the future compared to banks with a lower $\mathrm{P} / \mathrm{E}$.

Capital Adequacy Ratio (CAR) is the ratio of a bank's capital in

Capital

10. Adequacy

Ratio relation to its risk weighted assets and current liabilities. It is determined by RBI to thwart commercial banks from taking surplus leverage and becoming insolvent.
Current Ratio =

Current Assets/Current Liabilities

Quick Ratio =

(Cash + accounts receivables + marketable securities)/Total Current Liabilities

Loans to Deposit Ratio $=$ Loans $/$ Deposits

Return on assets $=$ Net Income/Total Assets

Return on Equity =

Net Income/Shareholder's Equity

Earnings Per Share $=($ Net Income -

Dividends on Preferred Stock)/Average

Outstanding Shares

Net Profit Margin $=$ Net Profit $/$ Revenue

Asset Turnover $=$ Sales or Revenues $/$ Total Assets

$\mathrm{P} / \mathrm{E}$ Ratio $=$

Market Value Per Share/Earnings Per Share

Capital Adequacy Ratio =

(Tier I + Tier II + Tier III

(Capital funds)/Risk weighted assets

The risk weighted assets take into

account credit risk, market risk and operational risk. The Basel III norms stipulated a capital to risk weighted assets of $8 \%$. However, as per RBI norms, Indian scheduled commercial banks are required to maintain a CAR of $9 \%$ while Indian public sector banks are emphasized to maintain a CAR of $12 \%$.

Interest Coverage Ratio $=$ EBIT/Interest Expenses
Interest coverage ratio can be classified as a Solvency Ratio-which helps to understand if the organization is solvent and whether there are any near threats pertaining to bankruptcy.

Interest The interest coverage ratio is a measure of the number of times

11. Coverage Ratio a bank could make the interest payments on its debt with its earnings before interest and taxes, also known as EBIT. The lower the interest coverage ratio implies the higher the bank's debt burden and the greater the chance of bankruptcy or default. The higher the interest coverage ratio represents the less the chance of default. 